\title{
State and Civil Society Relationships in Indonesia: A society-oriented Reading in Search for Democratic Space
}

\author{
Aris Arif Mundayat, Pitra Narendra, Budi Irawanto ${ }^{1}$
}

\section{Spotlighting the State: Political literature in Indonesia}

Indonesia occupies a special place in Southeast Asian studies literatures not only because it is the largest plural society and most populous nation in this region, but also because of the political dynamics of transition from the authoritarian regime to democratisation. Since the reformasi (reformation) which commenced by 1998, Indonesian politics has entered a new phase of democratisation characterized in particular by the policies of decentralisation. This has fostered greater autonomy in governing political and financial affairs at the provincial and especially at the regency/district levels.

The New Order state model gained the attention of academics, especially political scientists, historians and anthropologists. Over the years the focus on the state was somewhat reversed, especially after the dismantling of the Suharto regime, but it remains strong. In general, the scholarly approaches to the study of Indonesian politics in the wide sense of the term either focus on the state institutions or civil society politics.

The first type of analysis emphasises the ways in which state subjugate most elements of society structurally, including the political economy. For these scholars, the state produces the socio political dynamics and the state becames the source of changes at the societal level. This is usually referred to as top down political changes or what Liddle (1973) calls as 'evolution from above'.

The state-centred analysis has produced knowledge on elite behavior in economy and politics, and on the role of state institutions in maintaining social and political order. This type of analysis tends to focus on the centre and the elites, setting aside common people in local contexts. Consequently, their analyses of the relationship between state and society 
in Indonesia has located the state as an instrumental political entity. This in turn constructs our general knowledge of state and politics at large (Mundayat 2005:5).

Two of the pioneering projects on Indonesia that applied this type of approach were those of George Mc T Kahin (1952) and Herbert Feith (1962), working on the development of nationalism, the emergence of political parties, the establishment of legislative bodies and the state in general. Their studies induced many related research programs on Indonesia in the following decades. The new generation of academics then developed more refined models of analysis of the New Order state. Leading analysts included Karl Jackson (1978), with his 'bureaucratic polity' model; Harold Crouch (1979) characterising the New Order state as a 'neopatrimonial regime' that could not be combined with democracy; Herbert Feith (1980) again now emphasising the 'repressive developmentalist' aspects of the state; and Ruth McVey (1982), drawing attention to the historical colonial roots of the bureaucratic state in terms of 'beamtenstaat'.

In the 1980s, there was an important shift towards more structural and political economy oriented approaches. Richard Robison acknowledged the importance of capitalism in transforming Indonesian society and thus focused his study on the interaction of culture, economics, and political factors in understanding the foundations of the New Order regime (Robison 1981).

Robison (1981) and Hadiz' (1997) showed the importance of class struggle of workers in industrial areas that would contribute to political change as they organised themselves into trade unions. Meanwhile Törnquist (1982 and 1984) stressed the importance of primitive (coercive and politically organised) accumulation of capital and concluded thus that the related class conflicts could spur demands for democratisation.

In spite of the wider focus however, these analysts maintained that the state-society interaction is primarily framed structurally (Robison 1986, Robison \& Hadiz 2004). Although in their recent publication (Robison \& Hadiz 2004) Hadiz emphasises the role of politico-business oligarchic actors, his approach still views these actors as the actual masters of the political and economic life of the state and as structurally determined.

Moreover, all these types of approaches have actually contributed to the understanding that the state is too powerful and needs to be downsized through liberal markets and democracy. At this point however, the structuralists like Robison and Hadiz stressing the political economy were lost some on their influence in favour of institutionalism. Studies of power and democracy in Indonesia since the 1990s has mainly focused on the state institutions of democracy or state bodies (such as courts, legislatures, bureaucracies, and electoral system) and state enforced rules (constitutions, laws, and regulations). This focus on state institutions has had a systematic effect on political outcomes, such as the political reforms from 1998 until the early 2000s that promoted the formal core institutions of a procedural democracy. It is true that the analysts having emphasised 
that democratisation and institutional change was rooted in class conflict over coercive capitalism stressed the potential of not just citizen associations but also class based organisations e.g. Törnquist 1989, 1991 ), but the mainstream argument was rather of liberal civil society driven democratisation of state institutions, which in turn would get democracy on track (later on analysed by e.g. Aspinall 2005).

The latter argument was related to the arguments by researchers of Latin America such as O'Donnell and Schmitter (1986). They argue that all transitions toward democracy in 1970s and 80s Latin America began with a split in the regime, especially between hard-liners and soft-liners. This then followed by intensified mobilisation by democratic civil society and opposition forces which then pushed toward democratic transition through negotiation process. O'Donnell (1994) suggests for instance that the spotlight on the state institutions of democracy has been insufficient and elitist in nature. It has prevented a firm understanding of the role of civil society. Moreover, formal liberal-democratic institutions have dominated most of the public arenas and narrowed down all possible alternative and/ or additional representation fostered from below.

O'Donnell's (1994) "delegative democracy" work on Latin American democracies argues that many of the formal rules of representative democracy are weak. In this case he notes the effect of clientelism and other forms of particularism in undermining the effectiveness of representative institutions. This same argument of O' Donnell's can be found in the discussion about Indonesia's liberal oriented electoral democracy. For example, an extensive study was made of the post-Soeharto democracy movements (Prasetyo et.al 2003) and Törnquist (2004), based on Indonesia's first national democracy survey (later reported in Priyono et.al 2007). These studies speak of a 'democratic deficit'. The meaning of this deficit is that the quality of a number of formal institutions related to governance and especially representation is very poor. In addition, the ordinary citizens do not have the ability to improve and make full use of the new institutions. This creates weaknesses in vertical accountability/representation and in constitutional and legal checks and balances (patronage, corruption, and weak oppositional parties).

A related but more sociological and anthropological approach to the study of power and democracy can be found in studies that focus on the societal level of political life. In this category we may include classical perspectives such as those of McVey $(1965,1978,1992$,) and Benedict Anderson (1972a, 1972b, 1982, 1983) which differ from the polity oriented analyses in that they draw attention to the importance of broader studies of the Indonesian society to understand political life.

The significance of these studies lies in the role of civil society that encompasses civic, religious, kinship, and other "societal" rules and organisations. The studies of civil society institutions have long been a central object of study in the field of anthropology and Indonesian local politics(i.e. Antlov 1995). The prominent figure established the base body 
of knowledge of Indonesian studies at the everyday life level was Clifford Geertz. His important early work investigated the relations between the state and parties and the ethnic, religious, and cultural aspects of postcolonial Indonesia at the societal level rather than state level (Geertz 1960, 1963).

This kind of study has become important in Indonesia since the 1980s. For example, John Sulivan's (1992) study on urban kampong political life and Hans Antlov (1995) work on village politics show the role of the state in people's lives at the local level. However, even though their work at the local level focuses their attention on society, their studies remain influenced by the discourse that the state plays a dominant role at the local level.

These difficulties of moving away from state centrism have meant that the study of civil society institutions has not been rigorously conceptualised or theorised in Indonesian politics. Consequently, the civil society studies remain at the margins of the contemporary literature on political institutions of Indonesia.

Besides being under-theorised in the Indonesian context, civil society institutions of politics face problems from their counterparts, i.e. state institutions, the market and the associational life which is not based on citizenship rights such as groups based on religious and ethnic identities. The inequality of power relations (such as of of wealth, access, control, and influence) between, on the one hand, state as well as other dominant institution such as religious organisations and ethnic based communities (komunitas adat) which function as local equivalents of state organisations, and, on the other hand,civil society has produced problems for the process of democracy. This political inequality has several impacts, such as the lack of democratic governance, which influences the political behavior of elite and civil society, and undermines deliberative aspects of democracy. Civil society groups do not have the ability or the willingness to express their own reasons publicly and to consider the public reasons of others. Thus, the question of this study is therefore how it would be possible, in-spite of the uphill constraints, to bring those institutions into a productive synergy, to thus foster what we shall call 'democratic governmentality'.

\section{Mapping the Post-Reformasi Literature on State and Civil Society Relations}

This section maps and analyses the literature on state and civil society relationships. To gain an understanding of the relationship between state and civil society from the literature on the Indonesian context, we need to define civil society theoretically.

Agnes S. Ku notes that civil society in classical concept is not yet understood as a sphere of life distinct from the state. Rather as in 
Locke's liberalism, civil society is associated with political society and in opposition to the state. In further development of capitalism, there was a need to prevent state despotism by fostering self organisation within society. Hence it was argued that the state had to be restricted to protect citizen's life, liberty and property. Hegel envisages that civil society is a sphere where individuals with self interest enter into interdependent social relationships with one another, without sharing their optimism and inherently overwhelmed with egoism and conflict (Ku:2002). For Marx who worked within the framework of distinguishing between base and superstructure, the bourgeois civil society is understood to be rooted in the economic relations that operates under the logic of exploitative capitalism. Hence both liberal and Marxist traditions tend to relate civil society to the dynamics of the market economy. Gramsci (1971), however, stressed the importance of non economic forces in social life. He distinguished between state and civil society as two non economic modes of domination. While the state is an institution of political coercion for the dominant classes; civil society is the domain of cultural and ideological practices generating consent with the state governance.

Without negating these perspectives, we would argue however that they are inadequate to understand the complexity of civil society in the contemporary forms of capitalism in post-colonial contexts such as Indonesia. Rather we think that the definitions of civil society provided by Parson (1971: 24, 92-98) and Habermas' (1989 and 1996) are more fruitful. Their definitions are based on the distinction between three types of 'operative social organisations' consisting of money organised through the market, power working through administrative organisations, and influence that works through associations. These operative social organisations are mediated by communication which then constitutes a public sphere where these entities are interconnecting, influencing and mediating each other. Further more, according to Chandhoke, normatively, civil society represents an important stage in the transition from the family to the state. It is a space characterized by an explicit principle of particularistic individualism and implicit principle of communitarianism (Chandhoke, 1995). Then when they involve in the political project of civil participation are actually self limiting because their aim is not to capture the state but to expand the sphere of self organized out side the state (Chandhoke, 1995:30)

Civil society in European political context as Parson and Habermas argue is actually a social space because the members of this associative relations develop it for active communication and building up linkages for scaling up their interests. The space here is the domain for agencies to participate in and to contest, produce, reproduce and disseminate their ideas in relation to the state and market. The participants in this associative relation can be active or passive. This situation seems difficult to find it in 
post colonial state of Indonesia. Due to this I will use the concept of civil society as what Chandhoke(1995) argues before. The closest argument to support Chandhoke is as what Partha Chaterjee (2001) argues that:

"Most of the inhabitants of India are only tenuously, and even then ambiguously and contextually, right-bearing citizens... They are not, therefore proper members of civil society and are not regarded as such by the institutions of the state.

Following the condition of post colonial state as what Chaterjee explains, civil society in Indonesia remain debatable. Hence there are two possible characters of civil society - a strong civil society and a weak civil society. The civil society is strong when the space for associational relations enables the participants to develop equal political relationship with the state or market. Conversely, civil society is weak when it is unable to develop equal political relationships with the state or market.

This article will analyse the existing literature on the relationship between civil society and the state rather than the market. This is because we are discussing these issues within the context of what we shall soon define as governmentality. Assuming that civil society is an associational relation and the state is an administrative organisation, both of them are institutions in terms of formal and informal rules and regulations. Given that the relationship between state and civil society involves what we have called agencies, one needs to consider the relationship from the point of view of the actors and do away with assumptions of the state and civil society as self contained solid entities. Therefore, this study frames the state as part of everyday life practices, discursive and ideational. In this context, the state is not only a question of organised institutions, but also the ideas of managing and encountering government and agencies (Corbridge et.al 2005:5).

By employing this definition, the state can be understood more as ideational or as a form of governmentality. The term 'governmentality' itself was first used by Michel Foucault. He defines 'governmentality as the study of the "autonomous" individual's capacity for self control and how this is linked to forms of political rule.' (Foucault 1994: 221). The term of governmentality used to describe the way of administering populations such as through census and registration. This technique rise within the context of the emergence of the idea of the state in modern European history. This is not at the level of administrative or political practice but rather the techniques and procedures which are design to govern the conduct of both individuals and population.

The concept of governmentality helps us thus to understand the critical character of government. This in turn enables us to also take into account the conflicts and resistance that are put forward against technologies and rationalities of government. In accordance with this understanding, the relationship between state and civil society might take 
the form of different relations of power such as conflict, anarchy, clientelism and engagement. The form of power relations between civil society and the state in the Indonesian context can be mapped as in the matrix below.

Figure 1. The Forms of Power Relations Between Civil Society and the State

\begin{tabular}{|c|c|c|}
\hline CHARACTERS & $\begin{array}{c}\text { INEFFECTIVE STATE } \\
\text { TACTICS OF } \\
\text { GOVERNMENTALITY }\end{array}$ & $\begin{array}{c}\text { EFFECTIVE STATE } \\
\text { TACTICS OF } \\
\text { GOVERNMENTALITY }\end{array}$ \\
\hline $\begin{array}{c}\text { STRONG CIVIL } \\
\text { SOCIETY } \\
\text { WEAK CIVIL } \\
\text { SOCIETY }\end{array}$ & $\begin{array}{c}\text { (1)Alternative/ } \\
\text { resistance/ conflict } \\
\text { (Alternative governmentality) }\end{array}$ & $\begin{array}{c}\text { (4) Engagement } \\
\text { (Democratic } \\
\text { governmentality) }\end{array}$ \\
\hline $\begin{array}{c}\text { Militia/Paramilitary } \\
\text { (Extralegal governmentality) }\end{array}$ & $\begin{array}{c}\text { (3)Money politics, } \\
\text { patronage, clientelism, } \\
\text { cooptation } \\
\text { (Patronage governmentality) }\end{array}$ \\
\hline
\end{tabular}

The relationships between state and civil society in the matrix above, illustrate that we should consider whether governmentality is effective or ineffective. The effective state tactics of governmentality show that the power operates effectively through the process of government. This needs discipline from the state apparatus in implementing the state's programs. The state may also incorporate civil society as a participant in it. On the other side, ineffective state tactics of governmentality show the opposite characteristics.

One can differentiate between strong and weak civil society. First, strong civil society is the situation where the citizens and non-citizens are active and have capacity to organise to defend their interests politically and mobilise themselves for struggle to defend their interests. Second, a weak civil society is in the opposite situation. The citizens and non-citizens are less active or even passive in struggling to obtain their interests politically and they do not have the capacity to organise themselves for their own political purposes.

To understand civil society in Indonesia from this point of view the discussion in the following section will follow the logic of the relationships as indicated in the matrix.

\section{The First Forms of State-Civil Society Relations: Alternative governmentality}

The first pattern of power relations between state and civil society in Indonesia is that of alternative/counter/resistance/conflict. This type of power relation is formed when state tactics of governmentality are ineffective, and when civil society is strong. The reasons behind the ineffective state tactics of governmentality can be identified as limited 
state intervention in the public life because of several reasons such as the absence of a particular state policy as in Manurung (2007), Kusnadi (2007), Dewayanti \& Chotim (2004) and inefficient bureaucracy, corruption, collusion, nepotism as seen in Nasir's et.al. (2007) research findings.

An initial example is when Sujuthi (2001), Siregar (2004), and Ishak (2004) find that the non-participative policy does not fulfill local interests and needs, which then local people tend to resist as policy from above. From the existing literature we can see the state's relative absence in the public sphere has created the pathway for several elements of civil society to emerge such as NGOs to empower marginalised groups at the local level (the poor, women, ethnic minority)through several tactics. For example, NGOs provide these groups with assistance for socio-economic and political empowerment, including giving them education (Manurung 2007), political advocacy (Dewayanti \& Chotim 2004, Hendarta, 2005), and advancement in organisational capability and mobilisation (Makinudin 2004, Dewayanti \& Chotim, 2004, Hendarta 2005).

The literature shows that the involvement of NGOs has stimulated alternative governmentality as Appadurai (2002) notes in his research in Mumbai, where local people have their own ability to administer their population at the local level. In the Indonesian case, this is obtained by creating alternatives based on customary law (Hendarta 2005), producing local knowledge to counter external ideas which are not participative (Baso 2002, Sinaga 2004), forming local state tactics of governance (Hendarta, 2005), and building community-based programs for self help because social welfare from the state is ineffective (Dewayanti \& Chotim, 2004; Makinudin 2004, Kusnadi 2007).

A similar case of alternative governmentality to that explained above, has emerged in Bali in the form of coexistence. One example is that which is found in the action called gabeng. The coexistence pattern has emerged due to the presence of two groups in the villages, i.e. those who are critical of and those who are in favor of the presence of investors (Dwipayana 2005:40).

The act of the customs in the village, once intended as institutions which guarantees the public good, public interest, and public properties, had undergone some transformation due to the temptation of capital accumulation introduced by the investors. This has caused some villages' officials to come up with the idea of renting customary land or even selling it to the investors.

To some extent there is also conflict emerging among the village inhabitants, especially when they use customary law as an instrument for strengthening their bargaining position against the government, the investors, and the migrant workers (Dwipayana 2005:40). In this case they make use of customary law for formulating their demands, such as gaining employment for local people within the territory of the customary administrative system (banjar) to work in hotels, preventing the entry of migrant workers, or even rejecting the presence of investors (Dwipayana 2005:41). 
Several power relations that exist between the state and civil society in different parts of Indonesia show characteristics of alternative governmentality rather than resistance or coexistance. This type of power relation is evident in several cases, such as education advocacy initiated by Butet Manurung amongst a marginal community in Bukit Dua Belas, Jambi (Manurung 2007); empowerment programme for marginalised woman conducted by ASPPUK (Asosiasi Pendamping Perempuan Usaha Kecil, the Women Association for Small Scale Business Assistance) (Dewayanti \& Chotim 2004); the Dayak Meratus community in South Kalimantan who refuses to embrace state-sponsored religion and, rather, create local myths to justify their existence (Baso 2002); the Simalungun Christian community struggling to create their own alternative church separated from the colonial tradition.

Moreover, the revitalisation of autonomous local government institutions in "Binua" and the re-enactment of Dayak's customary law in Landak West Borneo, show that a self-governing Dayak community is emerging to prevent further exploitation over the customary land by the investors (Hendarta, 2005).

An interesting case that has the characteristic of promoting alternative governmentality is the empowerment programme for marginalised women. ASPPUK's empowerment program highlighted structural problems causing marginalisation of women and small enterprises. ASPPUK's-research conclude that small enterprises run by women could not advance because of marginalisation and exploitation orchestrated by the state. Marginalisation occurred because the government's development programme did not include villagers as its subjects. The ASPUK's programme took two types of small enterprises in two villages in Java, firstly the coconut sugar industries in the Banyumas regency and secondly, the roof tile home industries in the Klaten regency.

I these enterprises ASPPUK found that women and their problems cannot be separated from the discourse of women and development. This is because cultural as well as structural problems are at the root of public policy which inhibit women from fully participating in decision making processes (Dewayanti \& Chotim 2004: 126). Because of this, the government's policy did not support small village enterprises which mostly involve women.

However, the state policy favourably supported big and middle scale enterprises through financial support, despite the better performance demonstrated by small enterprises. This shows that the state does not consider the potential, the aspirations and the rights of women in accessing productive resources. Consequently, women are marginalised and forced to seek informal sources of capital, such as from moneylenders and loan sharks (Dewayani \& Chotim 2004:12-3).

The existence of informal sources of capital makes the condition of women's home industries even worse. This is because moneylenders and big traders control economic resources, product marketing and distribution. 
Women in home industries in this situation are borrowing money from the lender who then has the right to sell their product or they must buy raw materials from the money lender or big business. Unwittingly, women enter into a trap of unequal power relations with market (Dewayani \& Chotim 2004:83).

This shows that the state tactic of governmentality is ineffective because the state is hindered by the state apparatuses' vested interest. To avoid this situation ASPUK created a self-help group for women which assists them to avoid loan sharks. This is a good example of a alternative governmentality.

Another example of the character of state-society relationships is counter-governmentality emerging in a group of young people who encourage the local community to take a critical stance in response to social problems. This group finally chose media as a means to foster social change in their village.

This is apparent in the case of the "Angkringan" bulletin published for the first time in January 2000. The Angkringan community used a bulletin format to make it simple, accessible and cheap. This bulletin was designed to be a forum for villagers to express their ideas, suggestions, and criticisms about social problems around them. The villagers are enthusiastic about this community media that enables them to get information regarding their neighbourhood. This media constructs a kind of consciousness that information is important and functions as a political channel.

The "Angkringan" radio is the second instrument that empowers villagers alongside the bulletin, because most of Timbulharjo villagers are illiterate, especially the elderly. One of the radio's popular programs is "Obrolan Angkringan" (Angkringan Talk). This program raises current social issues that attract villagers' attention, such as education, agriculture, security and politics. This program is useful for finding solutions to the social problems they face. The talk show gives villagers the opportunity to involve themselves in this program in which they have an ability to find a solution.

This talk show has had a political impact and influenced some changes in village policies, such as correcting the misappropriation of the Fund for Alleviating Urban Poverty (FRUP), exposing the stagnancy of the Peasant Working Credits (PWC), encouraging accuracy in the Fuel Compensation Fund (FCF) and in observing the local election. In the Fund for Relieving Urban Poverty (FRUP) case, the program operator apparently colluded with the local cooperatives (koperasi) operator by lending the fund to villagers with a higher interest rate. Consequently, the poor, who should gain access to easy credit, could not get any benefit from this program. The Angkringan's confrontational tactic is shown in its bulletin and radio, according to Nasir (2007, p.60), this is effective for giving shock therapy to the corrupt local state apparatuses and, at the same time, encouraging the members of the community to act critically and develop their ability as a local government watchdog. 
Community media also has several other advantages (Nasir et. al. 2007:23-5). First, community media brings information that is useful for the community when observing the implementation of government projects in their neighbourhood. The availability of information increases the community's capability to solve their problems. Second, community media are able to gather information from community members which can then be used by government for formulating development policies. Hence, accurate policies can reduce the emergence of misappropriation of funds, community discontent and social conflict at the local level.

Grassroots political practices as discussed above can be categorised as counter/alternative/coexistence-governmentalities since they place themselves on the opposite side to the local government. Moreover, their critical attitudes as well as their criticism of local bureaucracy's misappropriation of funds, corruption and collusion can be added as another reason to put them into this category. Furthermore, NGOs in this case play an influential role in encouraging community members to become more active in participation and critical analysis, as well as to have the ability to observe local governance practices but that do not yet promote a form of engagement.

\section{The Second Form of State-Civil Society Relations: Extralegal governmentality}

The second pattern of power relations between the state and civil society in Indonesia is manifest in a form of anarchy. This type of power relation is formed when both state and civil society forms of governmentality are ineffective.

The reasons behind the state's ineffective governmentality can be identified as limited state intervention in public programs due to several reasons, such as the absence of a particular state's public and social policy and inefficient bureaucracy. The state's relative absence in the public community has allowed violent elements to play a role in it. Brown and Ian Willson (2007) note that the collapse of Soeharto's New Order regime has resulted in a fragmentation of its patronage networks. This has prompted a decline in state-sponsored violence but at the same time the number of non-state groups employing violence and intimidation as a political, social, and economic strategy has increased in many ways. These violent pressure groups have appeared in many spaces of life, using the identity of a certain ethnic group, religion, political party or social group. This is the residue of the New Order regime which tended to groom groups of thugs to be "the clean up machines" in order to ensure the smooth implementation of a number of elites' cum state's projects. Any state violence conducted to muffle democratic voices from the grassroots, included ethnic violence. (Brown and Wilson 2007).

Brown and Wilson (2007) note that civil 'bosses' produce this machinery of violence parallel with the implementation of district autonomy. This machinery has become a 'moneymaker' which enables the 'bosses' to 
'play' their violent 'business' as guardians of gambling business in Jakarta or as militia of political party.

This phenomenon is not new, paramilitary, vigilante, and militia groups have a long history in Indonesia. For instance, the guerillas that fought against the colonial army were originally formed from such groups. This points to the long-standing historical ambiguity between "legitimate" and "illegitimate" violence. In fact, whether in historical times or in very recent ones, the thugs are quite often acting as "assistants" to the military or police by employing methods of physical and psychological intimidation as a means for holding effective power in society. (Brown and Wilson 2007)

More than that, the symbiotic relationship also exists between street-level preman (thugs) and the military and the political elites. Through this relationship, preman have the privilege of carrying out their own activities as guardians, e.g., control over specific sectors of the local economy (usually gambling, prostitution and other black market activities), in return for bribery of the state officials, allowing the thugs to have direct channels to almost all level of police or military. Violence, criminality and military or police backing are normal and common practice for gaining additonal income. Violent gangs and local 'strong men', known under a variety of names such as jago, jawara, bajingan and more recently preman, are the product of a widespread culture that emphasises masculinity, martial arts, and superstitious powers. (Brown and Wilson 2007)

They have been central yet ambiguous figures throughout the history of the archipelago from the colonial period, such as the legend of Pitung in Batavia, to the present. Pitung is considered to be a cultural icon of Batavian opposition during the colonial time. The history of Pitung remains in the memory of local people and his struggle has inspired the emergence of pressure groups in Banten. Today, the legend of Pitung'has been transformed into hundreds of preman groups ready to provide safety and security services for the business sector. One amongst many is FBR (Forum Betawi Rempug, The Betawi Brotherhood Forum) which literally occupies Mega Kuningan Central Business District. The FBR denies the allegation that they are street thugs, and assert the purity of the Betawi culture in contrast to the corruption of the wider society (Brown and Wilson 2007).

FBR, along with FPI (Front Pembela Islam, The Islamic Defenders Front), have emerged as a consequence of the fragmentation of post1998 state power. They have constructed Betawi and Islamic identities by employing cultural symbols and mythology associated with the cultural hero of Pitung. He is depicted as the quintessential jawara (martial art champion), both an outlaw and a figure of respect and influence amongst the community, a kind of locally-made Robin Hood. FBR claims to represent working-class members of the indigenous Betawi ethnic group of Jakarta. It combines appeals to ethnicity and class with a strategy of extortion and coercion. 
Sidel (2007) advances the argument that religious violence in Indonesia belongs to a particular narrow period (2000-2004), and as the product of distinct political and social developments in the country. He argues convincingly that the cases of religious violence were the result of a reversal of political fortunes amongst the advocates of Islam after 1999, rather than a rise of Islamicism in mainstream Indonesian politics. He also points out that religious violence usually occured with direct support from members of the Indonesian military. This support had different motives, ranging from sympathy with the Islamists to attempts to undermine the country's political leadership, to internal factional disputes and rivalry with the Police.

Cases of vigilanteism are found in Madura as noted by Masaaki and Rozaki (2007). In the regencies of Sampang, Bangkalan, Sumenep and Pamekasan, the administration is dominated by various such groups, including sucthe kiai (the Islamic teacher), the army, or even kiai-Blater. Blater is a kind of thug figure who is respected in Madurese society because in Blater's hand, the authority can be decided.

Suryawan (2007) in his notes reports that a similar case exists in Bali, where there is pressure group called pecalang (traditional militia). To some extent, the existence of pecalang has become a competitor for police or private security guard. They have their own territory based on the adat law. This kind of militia is very potential for conflict, especially when it is used for political purposes.

Political parties are not immune from the use of violence, employing party-affiliated security task force or satgas (militia) prepared which are organised to employ coercion. During the 1980s, these groups were associated with the state-sanctioned parties, the Golkar (Golongan Karya = Functional Group) party, PPP (the Islamic-oriented United Development Party) and the PDI (the Indonesian Democratic Party); there was also the the Pemuda Pancasila (The youngsters of Pancasila) as the youth wing supporter of Golkar. The satgas competition began in 1999 with the reintroduction of the multiparty system. This function for internal party security, such as protecting party assets and controlling the membership. However, the satgas have also engaged as private mercenary armies, intimidating opponents and critics both within and outside the party, providing bodyguards for the private sectors and operating their own protection rackets alongside other criminal activities or backing up gambling business, smuggling and prostitution (Brown and Wilson 2007). Furthermore Brown and Wilsons argue that reformasi implied the liberalisation of both party politics and underworld criminal activities. The satgas have been the most astute beneficiaries of both processes. For the major parties, the satgas are little more than private armies. The internal structure of satgas units replicates military orders of hierarchy from the regional commander down to the platoon. (Brown and Wilson 2007)

The extralegal governmentality discussed above shows that the state tactics of governmentality have failed to provide legal, social, and 
political protection of its citizens. This 'responsibility' has been taken over by the thugs with extralegal methods. Indeed this has become very counterproductive for the equal political relation between state and civil society. The emergence of the extralegal form in civil society through the third party has partially been normalised in everyday life practice, because people cannot rely on the police to protect themselves. To some extent, the police and military even gain side incomes by backing up the militia groups' protection of prostitution and gambling bussineses (Mundayat, 2005; Brown and Willson, 2007).

\section{The Third Form of State-Civil Society Relations: Patronage governmentality}

Patronage governmentality emerges in the situation where the power relations between state tactics of governmentality are effective but when civil society is weak. There are many forms of patronage governmentality. The most well know ones relate to patron-client relations and the co-option of people into various dominating governance agencies. However, we may also include more paternalistic forms of top-down state patronage. The latter situation characterises power relations between state and civil society in the Jembrana Regency, Bali. An illustrative case is the eradication of corruption and the optimal utilisation of the Government Budget for improving people's prosperity (TIFA, 2005). The local government of Jembrana have implemented their program by eradicating the most infamous problem in Indonesian bureaucracy: corruption amongst public officials. Moreover, the local government has tried to utilise their budget for developing and improving the standard of living of the local community.

The fundamental change in the government administration system of jembrana has been in developing financial efficiency in order to provide better public services. The Bupati (district head) started it by making priority of programs expected to raise the prosperity of the populace. The efforts have focused on providing basic human needs in three sectors: education, health and economy. In the education sector, the local government of Jembrana has tried to be efficient by grouping several understaffed elementary schools into one management.

This strategy allows the district government to save up to 3.3 billion Rupiah per year. Meanwhile, the local government also planned to reduce the number of drop-out students in their regency. One of the programmes is the waiver of tuition fees for students in elementary school (SD), junior high school (SMP), senior high school (SMU), and vocational high school (SMK). The district government also provides scholarship for students who study in private school. The local government was, moreover, able to reduce the number of drop-out students in the regency and achieve success in implementing the national program of nine years of basic education.

The local government of Jembrana has also made significant reform in the health sector. The health problems faced by people in Jembrana are typical to the rest of Indonesia i.e. people experienced 
difficulties in accessing public health services, especially in local health centres (puskesmas) and hospitals, due to their economic condition. In order to solve the problem, the local government of Jembrana made a bold breakthrough. They stopped drug and medical subsidies in local health centres and hospital and then shifted it to fund health insurance premiums for the people, especially the poor. Every Jembrana citizen has the right to receive the insurance, with which the poor can access public health services around Jembrana free of charge. The local government also provides services for the poor families by providing them with free hospital services.

In the economic sector, the local government of Jembrana provides funds for supporting the local economy. The Bupati prioritises the distribution of funds to poor and small-medium enterprises. This fund is to boost local economic activities through entrepreneurship credits for the local community especially for those who work in the agricultural sector. It is important for Jembrana because this district does not rely on the tourism sector but rather agriculture. The Bupati has designed the Jembrana economy to become the agricultural base for areas of Bali that are dependent on tourism. This is in order that Bali is not dependent on rice and other agricultural products from outside Bali. More than that the support fund is utilised for stabilising crops prices and boosting agricultural productivity.

The local government of Jembrana has also succeeded in lowering the incidence of corruption. At the same time, it has made the local bureaucracy efficient and improved the performance of local public servants.

However, all these efforts have been without active people's participation. By conducting such top-down development under the control of the district head and the state apparatus, the local government of Jembrana thus practices a form of patronage governmentality. This character of governmentality does not even stimulate civil society to be more active in participating in development programs. By contrast, the local government of Jembrana has managed to involve business people in the local development process. In short, the relationship between the district head of Jembrana, economic society and elements of civil society is a form of the patron-client relationship. The local government mobilises the local community in the decision making process in order to obtain support for the implementation of local government's policies.

\section{The Fourth Form of State-Civil Society Relations: Engagement or collusion?}

The fourth pattern of power relations between state and civil society can be referred to as a form of engagement. This type of power relation is formed when the state tactics of governmentality are effective and when civil society is strong too. Effective state governmentality can be seen from the state's efforts to manage good governance practices, such as assisting 
local community development, promoting public health services, providing cheap or even free education, and offering working credit that promotes the local economy through a process of participation. Meanwhile, civil society is strong when they participate in every activity of a development program. This situation enables a form of engagement between state and civil society. This relationship between state and civil society has the potential for substantive democratic practices. Both parties work together to empower civil society by providing help and assistance.

Several cases of power relations between state and society point however to collusion rather than engagement. This is counterproductive in terms of developing a democratic governmentality. The collusion between state apparatuses and civil society in this case tend to be elitist, since it only favours some top members of both parties as demonstrated by Sujuthi (2001) and Dwipayana (2005). Meanwhile, the rest of civil society hardly gains any direct advantages from the relationship. In some cases, the civil society acts only as an instrument of the local elites for pursuing their personal goals (Suryawan 2005).

A case of collusion that involves government and elements of civil society occurred in Bali. It was based on a mutual understanding between elements of civil society, i.e. the customary village and the provincial government of Bali. The customary villages only acknowledged the puri's (royal family members) authority in cultural matters while the state was charged with public affairs. Dwipayana (2005:87) goes even further by saying that there has been an ongoing process of sacralisation and domination of the state's authority in Balinese society. The state tended to replace the roles once played by the kings in the past. The adat villages were even more dependent on the state in solving and handling their public affairs. Furthermore, the village was taken advantage of by external investors and their government related partners.

This has led the customary villages to respond in an accommodative way which makes them vulnerable to the practice of collusion. This response emerged due to a number of opinions emerging as local rumours. For example it was rumoured that investors were able to alleviate the poverty problem in their village. This rumour promotes opportunities for locals to be involved in collusion with the local government through supporting the investors to invest at the local level. (Dwipayana 2005 p.39-40).

Another incidence of collusion that deserves attention is the case of Tarekat Rejoso in Jombang, East Java. This incident portrays how collusion took place between the state and civil society, in particular the Muslim community. during the New Order regime. The relationship between state and the Muslim community during the New Order regime, according to Abdul Aziz Thaba (in Sujuthi 2001), can be divided into three periods.

The first is a period where an antagonistic relationship developed (1967-1982). This situation occurred when the aspirations of some Muslim leader to participate in political life did not match with the New 
Order regime's plan to marginalise political parties and to outlaw ideologies outside Pancasila (the state's official ideology).

The second period was a period of a critical-reciprocal relationship (1982-1985). This relationship developed because of the growing awareness by the state and the Muslim community of the need to understand each other's position.

The third period is refered to as the accommodative relationship period (1985-1994). It was established when the Muslim community felt confident that the New Order regime would not secularise Indonesia by implementing the principle of Pancasila. This period was marked by the lifting of the ban on veils in public schools, the enactment of National Education Law (which included the religious boarding schools pesantren), the enactment of the Religious Court Law, etc.

Muslims enjoyed greater freedom in expressing their religious beliefs, as long as it did not contradict the state's ideology. Within this situation, Sujuthi notes that Islamic sect (tarekat) based on pesantren (religious boarding school) had a strong relationship with the state during the New Order.

On the one hand, the tarekat occupied a special place in the New Order's politics because of the presence of its charismatic religious leader, the Kyai. The Kyai had large capacity for mobilising people, the santri (pupils of boarding school), and at the same time, the New Order regime wanted to use them to their political advantage during the general elections (Sujuthi 200:xx).

On the other hand, the tarekat was powerless when facing the New Order regime. The tarekat did not have enough funds to develop facilities for the pesantren due to their social-economic weakness. They had to ask the government for help in funding this development (Sujuthi 2001, p.195). Many tarekat also sought government help in their dakwah (proselytising). This situation promoted collusion between the two parties - one for the purpose of pesantren development and the other one is for the political purpose of supporting the ruling party.

There were several reasons for Kyai Ramli's of Tarekat Rejoso to join Golkar. First, he wanted to advance his tarekat, his pesantren, and his Darul Ulum University. In order to do this, Kyai Ramli believed that the government's support and cooperation was essential, especially in providing funds for developing the pesantren's facilities (Sujuthi 2001, p.68). Second, Kyai Ramli had a hidden agenda in joining the Golkar party. Of the four big pesantren in Jombang, his pesantren was the only one that did not have a figure at the national level. Apparently, there was some kind of social status jealousy; some weakness and backwardness that need to be overcome by Tarekat Rejoso. Third, there were political pressures from the government, hindering the tarekat from conducting their mission.

The New Order regime controlled almost every aspect of social life, including much of the religious activities (Sujuthi 2001, p.69). This applied to tarekat followers. Many tarekat activities were suspected of being 
politically oriented and, hence, religious praying became complicated. According to Sujuthi (2001, p.76), Kyai Ramli joined Golkar in his personal capacity which then assisted his institution in obtaining many benefits from Kyai Ramli's position in Golkar. They received aid and facilities from the government. Moreover, many high-ranking officials from provincial government visited Tarekat Rejoso which, according to Sujuthi (2001, p.168), reflected the government's positive attitude toward them.

Meanwhile, the participation of Kyai Ramli in Golkar brought many advantages to this party. According to Sujuthi (2001:70), Kyai Ramli helped Golkar to broaden its influence to the santri group and to gain support from them. By gaining support from the santri group, Golkar also gained political legitimacy among Muslim communities by producing a new image as a non-secular party. These advantages made Golkar able to win the support of the santri group and secure its domination in the general elections.

This kind of political relationship to a great extent is not a form of engagement but rather of collusion in the interest of both parties. Their target is to obtain benefit for their own groups' interest rather than for the society in general. Political pragmatism for organisational gain and benefit is the main purpose in this case rather than promoting democratic governmentality and political equality.

\section{Conclusion: In Search of Space for Democratic Government}

This paper has shown how the relationship between state and civil society in Indonesia is part of the problem of building democratic government. The problems in Indonesian society is the polycentric nature, by which civil society organisations or popular organisations are being fragmented and often unorganised. This has made it increasingly difficult to transform various conflicts into more political through democratic institution. At least there are four major problems:

The first problem is when a strong civil society faces an ineffective state tactic of governmentality. This tends to stimulate civil society resistance and conflict; or it fosters coexistence through alternative governmentality techniques where the relationship between the state and society is in conflict.

The second problem is when a weak civil society faces an effective state. This tends to trigger practices of money politics which are embedded in patronage and clientelism. Generally this tendency can be found in areas with a strong traditional character. Here the remnants of the New Order regime are important within politics and patronage and clientelism remains significant within politics. As show in this article, there may also be cases of top-down state patronage.

The third problem can be found in the situation where weak civil society faces an ineffective state which tends to stimulate the emergence of extralegal governmentality practiced by thugs, militia, vigilantes and paramilitaries. This leads to a deficit in the democratic governmentality, which is whenpeople with more or less citizen rights internalise and practice more equal relations of power. 
The fourth problem is reflected in the situation where a strong civil society faces an effective state. Ideally this condition should promote engagement between state and civil society. In fact it is hardly evidence. What usually happens is an engagement in a form of collusion for their benefit. This collusion happens when civil society view the state as an instrument for economic, social, political, and cultural resources negatively, while the state apparatus views civil society as an economic resource only. This pattern neglects the importance of engagement that will become the base for democratic governmentality.

\section{Endnotes}

1 The authors wish to acknowledge with thanks a number of critical and constructive comments and proposals from the anonymous reviewers of previous draft versions of the article. 


\section{References}

Anderson, BRO'G 1972a, 'The idea of power in Javanese culture', in C Holt (ed), Culture and politics in Indonesia, Cornell University Press, Ithaca.

Anderson, BRO'G 1972b, Java in the time of revolution: occupation and resistance, 1944-1946, Cornell University Press, Ithaca.

94 Anderson, BRO'G 1983, Imagined communities: reflections on the origin and spread and spread of nationalism, Verso, London.

Antlov, H 1995, Exemplary centre, administrative periphery: rural leaderships and the new order, Curson Press, Richmond, Surrey.

Appadurai, A 2004, 'Deep democracy: Urban Governmentality and the horizon of politics'. Journal of Public Culture Vol 14 no.1, pp 21-47.

Aspinall, Edward (2005): Opposing Suharto: Compromise, Resistance and Regime Change in Indonesia (2005: Stanford University Press, Stanford)

Baso, A 2002,Plesetan lokalitas: politik pribumisasi Islam,Desantara, Jakarta.

Brown, D \& Wilson, I 2007, 'Ethnicized violence in Indonesia: the Betawi Brotherhood Forum in Jakarta, Working Paper, no.145, July, Murdoch University, Australia.

Chandhoke, Neera, 1995. State and Civil Society- Exploration in Political Theory. New Delhi: Sage.

Chaterjee, Partha, 2001. "Democracy and the Violence of the State: A political Negotiation of Death" in Inter-Asia Cultural Studies: p 8, 10.

Crouch, H 1979 Patrimonialism and Military Rule in Indonesia, World Politics, vol. 31, no. 4, pp.571-87.

Dewayanti, R \& Chotim, EE 2004, Marjinalisasi dan eksploitasi perempuan usaha mikro di pedesaan Jawa, Akatiga and ASPPUK, Bandung.

Dwipayana, AAGNA, 2005, Globalism: pergulatan politik representasi atas Bali, Uluangkep Press, Denpasar.

Feith, H 1962, The decline of constitutional democracy in Indonesia, Cornell University Press, Ithaca.

Feith, H 1980, The study of Indonesian politics: a survey and an apologia. In Herbert Feith. Repressive-Developmentalist Regimes in Asia: Old Strength, New Vulnerabilities, Prisma: TheIndonesian Indicator, Issue 19, December.

Foucault, M 1980, Power/knowledge, selected interview and other writing 1972-1977. Edited by Collin Gordong. Pantheon Books, New York

Foucault, Michel 1993, "About the Beginning of the Hermeneutics of the Self" (Transcription of two lectures in Darthmouth on Nov. 17 and 24, 1980), ed. by Mark Blasius, in: Political Theory, Vol. 21, No. 2, May, 1993, pp. 198-227.

Foucault, M 1994, "Subject and power" in Power, essential work of Foucault 1954-1984. Edited by James D. Faubion. Vol 3. Penguin Books. London. 
Geertz, C 1960, The religion of Java, Free Press, Glencoe.

Geertz, C 1963, Agricultural involution: the process of ecological change in Indonesia, University of California Press, Berkeley.

Habermas, J. 1987. The Theory of Coomunicative Action. Vol 2, Boston: Beacon Press.

1989, The Structural Transformation of the Public Sphere. Cambridge, MA: MIT Press

1996, Between facts and Norms: Contribution to a Discourse Theory of Law and Democracy. Cambridge, MA: MIT Press.

Hadiz, Vedi R 1997, Workers and the state in new order Indonesia, Routledge, London

Hendarta, B 2005, Tantangan pemberdayaan masyarakat adat di Kabupaten Landak Propinsi Kalimantan Barat, IRE, Yogyakarta.

Ishak, OS 2004, 'Konstruksi Konflik Aceh,' in L Triyono, et. al. (eds.) potret retak nusantara: studi kasus konflik di Indonesia, Yogyakarta, Centre for Security and Peace Studies, Gadjah Mada University.

Jackson, KD 1978, 'Bureaucratic polity: a theoretical framework for analysis of power and communication in Indonesia,' in $\mathrm{K}$ Jackson and L Pye (eds), Political power and communication in Indonesia, University of California Press, Berkeley.

Kahin, GMcT 1952, Nationalism and revolution in Indonesia, Cornell University Press, Ithaca.

$\mathrm{Ku}$, Agnes 2002, "Beyond the Paradoxical Conception of 'Civil Society without Citizenship" in international Sociology. http://iss. sagepub.com/cgi/content/abstract/17/4/529.

Kusnadi 2007, Jaminan sosial nelayan, Yogyakarta, LKIS.

Liddle, William 'Evolution from Above: National Leadership and Local Development in Indonesia,' Journal of Asian Studies, XXXII, No. 2 (February 1973), pp. 287-309.

Makinudin 2004, Air untuk secangkir kopi petani: refleksi pengalaman advokasi irigasi di Way, Seputih, Bandung, AKATIGA.

Masaaki, O \& Rozaki, A 2006, Kelompok kekerasan dan bos lokal di era reformasi, IRE, Yogyakarta. Manurung, B 2007, Sokola rimba, pengalaman belajar bersama Oran Rimba, INSIST Press, Yogyakarta

Maunati, Y 2004, Identitas Dayak: komodifikasi dan politik kebudayaan, LKIS, Yogyakarta.

Mundayat, A 2005, 'Ritual and Politics in New Order Indonesia: A Study of Discourse and Counter Discourse in Indonesia,' PhD Thesis, Swinburne University of Technology, Australia.

McVey, RT 1965, The rise of Indonesian communism, Cornell University Press, Ithaca.

McVey, RT (ed) 1978, Southeast Asian transitions: approaches through social history, Yale University Press, New Haven.Asia Program, Cornell University, Ithaca.

McVey, RT (ed) 1992, Southeast Asian Capitalist, Southeast Asia Program, Cornell University, Ithaca. 
Nasir, A et.al. 2007, Media rakyat: mengorganisasi diri melalui informasi,Yogyakarta.

O’Donnell 1994, Bureaucratic autoritarianism, Argentina, 1966-1975 in comparative perspective, California University Press, California.

O'Donnell, Schmitter, and Whitehead 1986, Transitions from authoritarian rule. Comparative perspectives. Baltimore : Johns Hopkins University Press.

Parson, Talcott, 1971. The System of Modern Societies. Englewood Cliffs, NJ: Prentice-Hall.

Priyono, A.E, Samadhi, Willy P, and Törnquist, Olle 2007. Making Democracy Meaningful. Problems and Options in Indonesia. Jogjakarta, Jakarta and Singapore: PCD Press, Demos and ISEAS. (1st edition 2005)

Qodir, Z \& Susan N 2004, 'Aksi radikalisme Islam,' in L Triyono, et. al. (eds) Potret retak nusantara: studi kasus konflik di Indonesia, Centre for Security and Peace Studies, Gadjah Mada University, Yogyakarta.

Robison, R 1981, 'Culture, politics and economy in the political history of the New Order,' Indonesia, Vol.31, April.

Robison, R 1986, Indonesia: the rise of the capital, Asian Studies Association of Australia, Canberra.

Robison, R \& Hadiz, V 2004, Reorganizing power in Indonesia: the politics of oligarchy in an age of markets, Routledge Curzon, London .

Siregar, LA 2004, 'Peta konflik Papua terkini,' in LTriyono, et. al. (eds.) Potret retak nusantara: studikasus konflik di Indonesia, Yogyakarta, Centre for Security and Peace.

Sujuthi 2001, Politik tarekat: studi tentang hubungan agama, Negara dan masyarakat,Yogyakarta, Galang Press.

Suryawan, N 2005,Bali: narasi dalam kuasa, Ombak, Yogyakarta.

TIFA 2005, Pembangunan (pro) rakyat telah dimulai, Yayasan TIFA,Jakarta.

Törnquist, Olle, 1989 \& 1991. What's Wrong with Marxism? Vo.1: On Capitalists and Statein India and Indonesia. Vol.2: On Peasants and Workers in India and Indonesia. New Delhi: Manohar.

Törnquist, Olle, 2004 'The political deficit of substantial democratisastion. in J Harris, K Stokke, and O Tornquist (eds) Politising democracy: the new local politics of democratisation, Palgrave McMillan, Hampshire and New York. pp. 201-25.

Touraine, A 2000, Can we live together: equality and difference, Stanford University Press, Stanford.

Wilson, ID 2006, Continuity and change: the changing contours of organized violence in Post-New Order Indonesia, Critical Asian Studies, vol. 38, no. 2, pp. 265-97,

Yunanto, S 2003, Gerakan militan Islam di Indonesia dan di Asia Tenggara, Friedrich Ebert Stiftung and The RIDEP Institute, Jakarta. 